\title{
TRANSFORMERLESS DOUBLE BOOST CONVERTER FOR NONCONVENTIONAL ENERGY APPLICATION
}

\author{
Harshal D. Vaidya ${ }^{1}$ \\ ${ }^{\text {I}}$ P.G. Student, Marathwada Institute of Technology, Aurangabad, Maharashtra, India
}

\begin{abstract}
This paper presents a Transformer less Double Boost Converter (DBC) which delivers a feasible answer for non-conventional energy applications. The proposed DBC combines the conventional boost converter and the switched capacitor function. The tactic is to achieve double output voltage compared to conventional boost converter using appropriate duty cycle. The key benefits of this topology are: a continuous input current, a double conversion ratio without extreme duty cycle and without transformer, which permit high switching frequency. Simply single switch, single inductor, three diodes, three capacitors are desirable to design proposed DBC. The constituents present in the proposed converter are designed using performance equations. The proposed DBC converter is planned for rated power $100 \mathrm{~W}$, output voltage $100 \mathrm{~V}$ with input supply voltage $20 \mathrm{~V}$. The proposed $D B C$ is simulated in MATLAB and simulation result will authenticate the legitimacy of the theoretical design.
\end{abstract}

Keywords: DC-DC; Double Boost converter (DBC); Single Switch. Non-Conventional energy.

\section{INTRODUCTION}

Various applications necessitate a dc-dc converter with high step-up voltage gain [1-10]. One of the most vital applications is the non-conventional energy generation, where the low voltage from a renewable energy source desires to be boosted for feeding a load or a grid connected inverter [2-6].To attain a very high voltage gain with customary topologies of DC-DC converters is difficult for the reasons such as: parasitic components, the condition of an extreme duty cycles or transformers limiting the switching frequency and systems scope [7-9]. Many topologies have been anticipated to overcome these challenges with high voltage gain without the usage of extreme duty cycles [10-27], with a relatively high complication compared with the traditional single-switch converters family; the current solutions for this challenge can be distributed into numerous categories.

In this paper a non-isolated Double Boost Converter (DBC) is recommended. This converter delivers a feasible solution for non-conventional energy applications. The proposed DBC combines the conventional boost converter and the switched capacitor function. The approach is to attain double output voltage compared to conventional boost converter using appropriate duty cycle. The foremost advantages of this topology are: a continuous input current, a double conversion ratio without extreme duty cycle and without transformer, permitting large switching frequency. Merely single switch, single inductor, three diodes, three capacitors are necessary to design proposed DBC. The essentials required in the proposed converter are designed by means of performance equations. The proposed DBC converter is designed for rated power $100 \mathrm{~W}$, output voltage $100 \mathrm{~V}$ with input supply voltage $20 \mathrm{~V}$.

This paper is structured as follows: Brief outline of recent DC-DC converter is delivered in section I. Conventional boost converter and proposed DBC is discussed in section II and III respectively. Operation Modes and Conversion ratio of proposed DBC is discussed in section IV. The proposed DBC is simulated in MATLAB and simulation results are deliberated in V. Lastly, conclusion is provided in section VI.

\section{CONVENTIONAL DC-DC BOOST}

\section{CONVERTER}

In DC-DC Boost Converter, the output voltage $\mathrm{V}_{\mathrm{o}}$ is larger than the input voltage Vin. The power circuit illustration of DC-DC boost converter is depicted in Fig-1. Single inductor, single diode and single switch are used to design Boost converter. The operation modes of boost converter can be distributed into two modes, one when switch $\mathrm{S}$ is turn $\mathrm{ON}$ and another when switch is turned OFF. When switch $\mathrm{S}$ is turned $\mathrm{ON}$, inductor is charged by input voltage Vin through switch S. Fig-2 clarify the operational mode when switch $\mathrm{S}$ is turned ON. In practical boost converter circuits, the switch and diodes has finite internal resistance. When Switch $S$ is turned OFF, inductor is discharged through load, diode and input voltage. Fig-3 describes the mode of operation when switch $\mathrm{S}$ is turned $\mathrm{OFF}$.

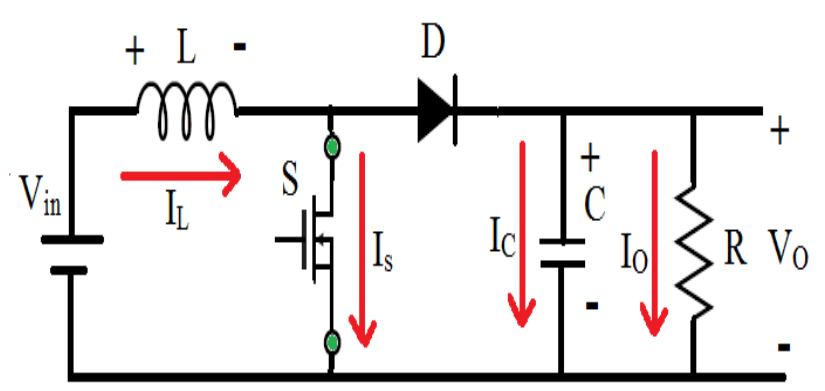

Fig-1: Power Circuit illustration of DC-DC Boost Converter 


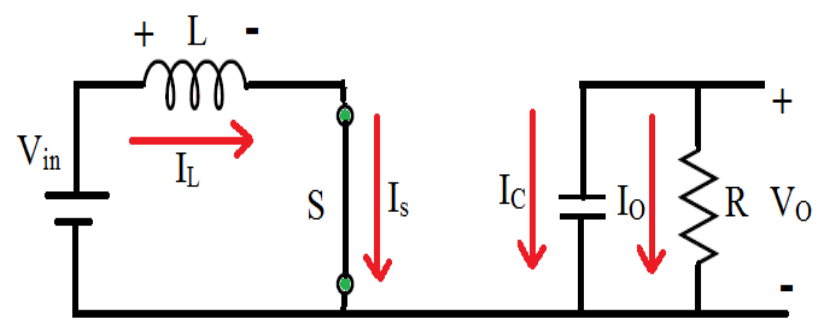

Fig-2: Equivalent Circuit of Boost Converter switch is $\mathrm{ON}$

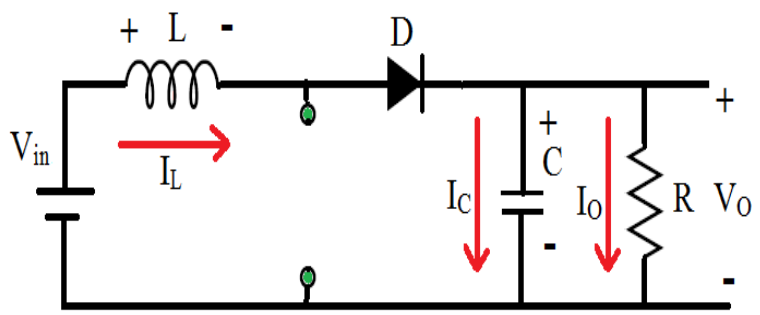

Fig-3: Equivalent Circuit of Boost Converter switch is OFF

If voltage across diode and switch is small then, $\mathrm{V}_{\mathrm{d}}=0$

$$
\frac{\mathrm{V}_{\mathrm{o}}}{\mathrm{V}_{\mathrm{in}}}=\frac{1}{(1-\mathrm{D})}(1)
$$

\section{DOUBLE BOOST CONVERTER (DBC)}

\section{CIRCUIT}

Double Boost Converter (DBC) circuit is exemplified in Fig-1. In proposed DBC, single inductor L is connected in series with voltage source. Single controlled power switch S with three uncontrolled switch i.e. diodes D1, D2, D3 are necessary to design DBC. Also, three capacitors C1, C2, C3 are required to boost the voltage. The arrangement of three diodes and three capacitors form a voltage doubler circuit at the output side of the converter.

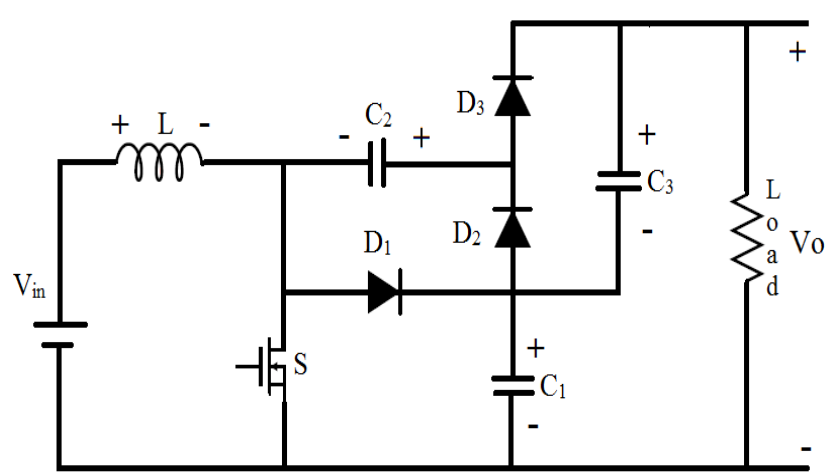

Fig-4: Circuit of Double boost converter (DBC)

\section{OPERATIONAL MODES OF PROPOSED}

\section{DOUBLE BOOST CONVERTER}

The operation of proposed converter is distributed into two modes, when control switch $\mathrm{S}$ is $\mathrm{ON}$ and another when switch $\mathrm{S}$ is OFF.
When switch $\mathrm{S}$ is turned $\mathrm{ON}$, inductor is charged by input voltage Vin through switch S. Capacitor C2 is charged by capacitor C1 through diode D2 and switch S. Finally, Capacitor $\mathrm{C} 1$ and $\mathrm{C} 3$ are discharged through load. The output voltage is equivalent to summation of voltage across capacitor $\mathrm{C} 1$ and capacitor $\mathrm{C} 3$. Fig-5 describes the mode of operation of DBC when switch $\mathrm{S}$ is turned $\mathrm{ON}$.

When switch $\mathrm{S}$ is turned OFF, capacitor $\mathrm{C} 1$ is charged through series connection of inductor voltage and input voltage through diode D1. Capacitor $\mathrm{C} 1$ and $\mathrm{C} 3$ are charged by series connection of capacitor $\mathrm{C} 2$, inductor voltage and input voltage through diode D3. Finally, the output voltage is equivalent to addition of voltage across Capacitor $\mathrm{C} 1$ and capacitor C3.

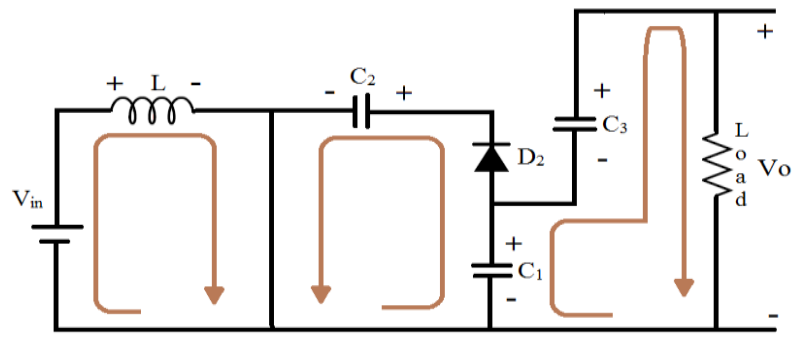

Fig-5: Equivalent Circuit and current direction of DBC when switch is $\mathrm{ON}$

Fig-6 clarifies the mode of operation of DBC when switch S is turned OFF.

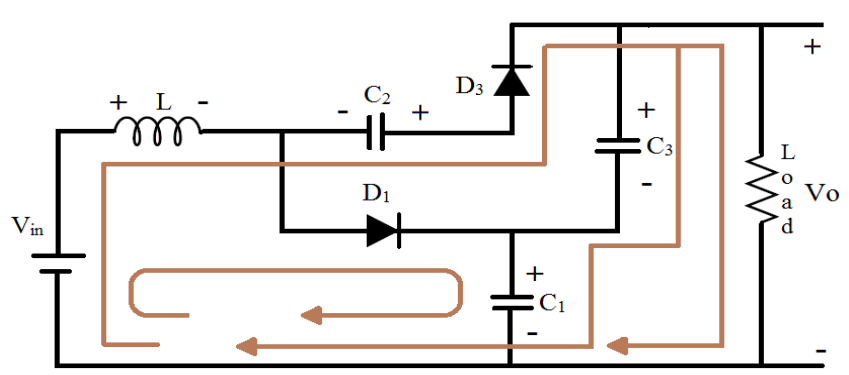

Fig-6: Equivalent Circuit and current direction of DBC when switch is OFF

If voltage across diode and switch is small then, $\mathrm{Vd}=0$

$$
\frac{\mathrm{V}_{\mathrm{o}}}{\mathrm{V}_{\mathrm{in}}}=\frac{2}{(1-\mathrm{D})}
$$

Thus, the gain of DBC is double as compared to the conventional boost converter.

\section{SIMULATION RESULTS}

The proposed Double Boost converter with the designed parameter is simulated in MATLAB/SIMULINK. The parameters value is listed in Table-I. 
Table-1: Designed parameters value

\begin{tabular}{|l|l|l|}
\hline No & Parameter & Value \\
\hline 1 & Input voltage & $20 \mathrm{~V}$ \\
\hline 2 & Output voltage & $100 \mathrm{~V}$ \\
\hline 3 & Output power & $100 \mathrm{~W}$ \\
\hline 4 & Inductor, Capacitors & $700 \mathrm{uH}, 220 \mathrm{uF}$ \\
\hline 5 & Switching frequency & $50 \mathrm{KHz}$ \\
\hline
\end{tabular}

Switch $\mathrm{S}$ is triggered by using pulse generator. The output voltage, output current and Input voltage waveform are displayed in Fig-7. The voltage and current ripple in output voltage is revealed in Fig-8. It is witnessed that the voltage ripple is $0.15 \mathrm{~V}$. Output power waveform is shown in Fig-9.

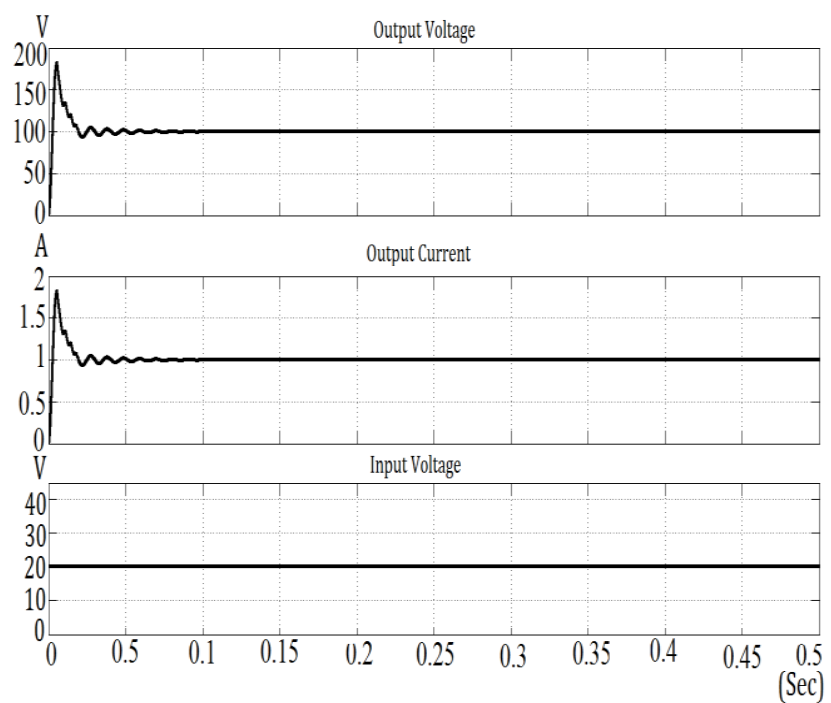

Fig-7: Output voltage, output current and Input voltage waveform
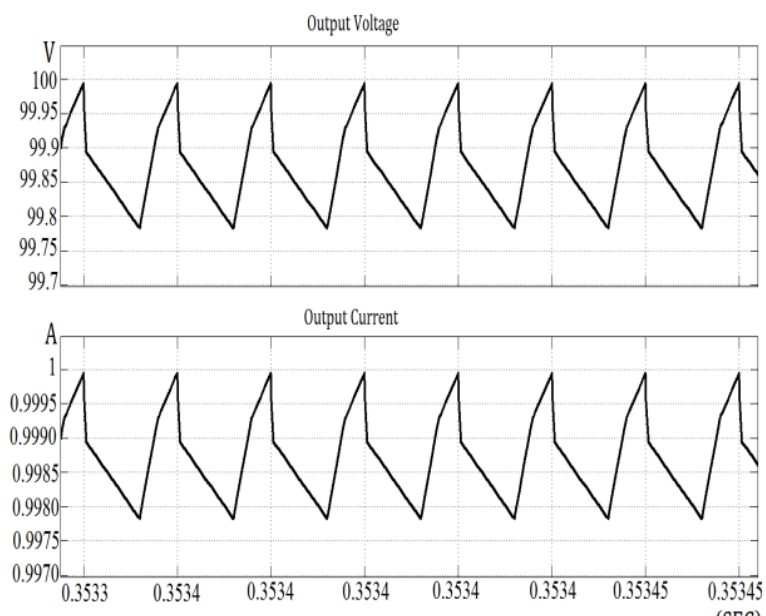

(SEC)

Fig-8: Voltage and current ripple in output voltage

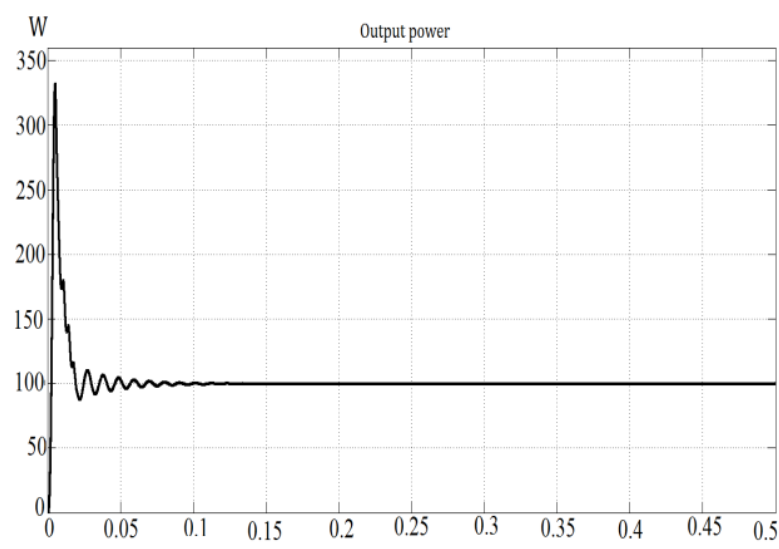

(SEC)

Fig-9: Output power of Converter

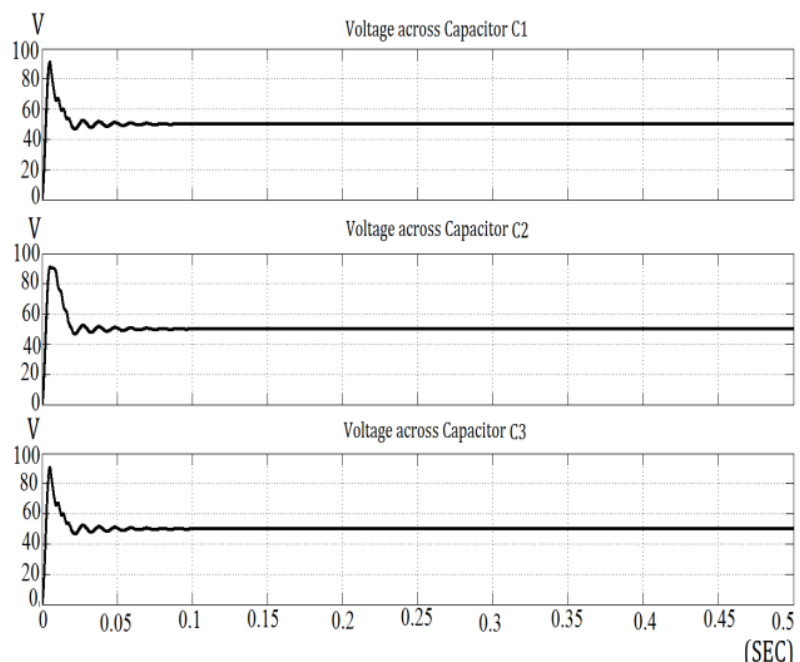

Fig-10: Voltage across capacitor $\mathrm{C} 1, \mathrm{C} 2$ and $\mathrm{C} 3$

Voltage across capacitor C1, C2 and C3 is shown in Fig-10. It is noticed that voltage across all capacitor is half of the output voltage i.e $50 \mathrm{~V}$. Voltage ripple across capacitor is displayed in Fig-11.

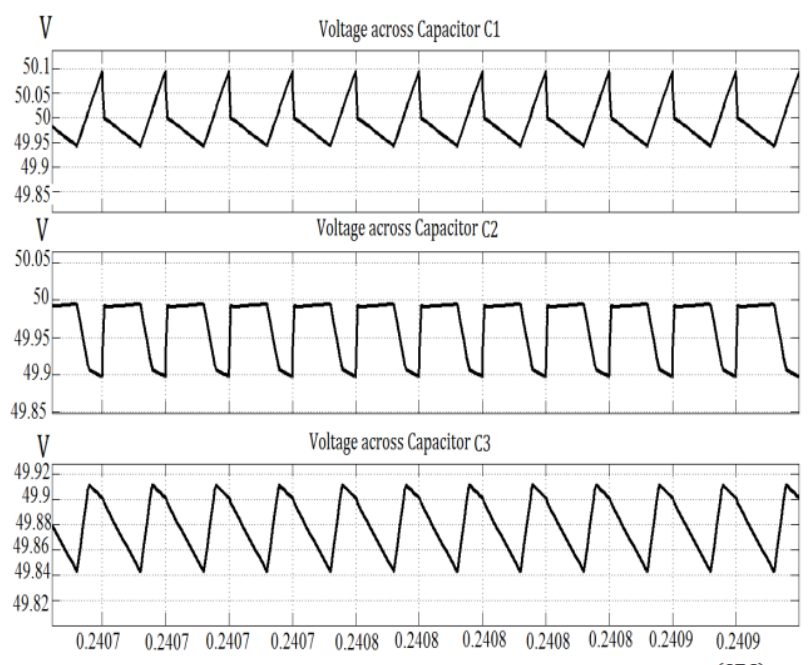

(SEC)

Fig-11: Voltage ripple across capacitor $\mathrm{C} 1, \mathrm{C} 2$ and $\mathrm{C} 3$ 


\section{CONCLUSION}

A non-isolated Double Boost Converter (DBC) is proposed for non-conventional energy applications to attain double output voltage compared to conventional boost converter by means of appropriate duty cycle. The proposed DBC conglomerates the conventional boost converter and the switched capacitor function. The main advantages of this topology are: a continuous input current, a double conversion ratio without extreme duty cycle and without transformer, which tolerate high switching frequency. Only single switch, single inductor, three diodes, three capacitors are obligatory to design proposed DBC. The proposed DBC is simulated in MATLAB and simulation results will confirm the legitimacy of the theoretical design.

\section{REFERENCES}

[1] Li, W; He, X; "Review of Non-Isolated High Step-Up DC/DC Converters in Photovoltaic Grid-Connected Applications," Industrial Electronics, IEEE Transactions on, vol. 58, issue 04, pp.1239-11250, 2010.

[2] Rong-Jong Wai; Wen-Hung Wang; Chung-You Lin; "High Performance Stand-Alone Photovoltaic Generation System," Industrial Electronics, IEEE Transactions on , vol.55, no.1, pp.240-250, Jan. 2008.

[3] Mahajan Sagar Bhaskar Ranjana, Nandyala Sreeramula Reddy, Repalle Kusala Pavan Kumar "A Novel Sepic Based Dual Output DC-DC Converter for Solar Applications" IEEE International Conference 2014 Power and Energy Systems: Towards Sustainable Energy, (IEEE-PESTSE) 2014, Banglore (India).

[4] Mahajan Sagar Bhaskar Ranjana, Nandyala Sreeramula Reddy, Repalle Kusala Pavan Kumar, Y. Bhaskar S S Gupta “ A Novel High step-up DC-DC Multilevel Buck-Boost Converter Using Voltage-Lift Switched-Inductor Cell" 2nd IEEE international conference on computer communication and systems (IEEE-ICCCS) 2014, Chennai, (India).

[5] Mahajan Sagar Bhaskar Ranjana, Nandyala Sreeramula Reddy, Repalle Kusala Pavan Kumar, Y. Bhaskar S S Gupta "A Novel High Gain Buck-Boost Multilevel Converter Using Double Voltage-Lift Switched-Inductor Cell" 2nd IEEE international conference on computer communication and systems (IEEE-ICCCS) 2014, Chennai, (India).

[6] Mahajan Sagar Bhaskar Ranjana, Nandyala Sreeramula Reddy, Repalle Kusala Pavan Kumar "A Novel Non Isolated Switched Inductor Floating Output DC-DC Multilevel Boost Converter For Fuelcell Applications" IEEE Students' Conference on Electrical, Electronics and Computer Sciences (IEEESCEECS) 2014, Bhopal, (India).

[7] Rong-Jong Wai; Chung-You Lin; Rou-Yong Duan; Yung-Ruei Chang; "High-Efficiency DC-DC Converter With High Voltage Gain and Reduced Switch Stress," Industrial Electronics, IEEE Transactions on , vol.54, no.1, pp.354-364, Feb. 2007.
[8] Mahajan Sagar Bhaskar Ranjana, Nandyala Sreeramula Reddy, Repalle Kusala Pavan Kumar, Y. Bhaskar S S Gupta "A Novel High Step-up Multilevel Boost Converter Using Double VoltageLift Switched-Inductor Cell" IEEE International Conference on Circuit, Power and Computing Technologies (IEEE-ICCPCT) 2014, Nagarcoil (India).

[9] Mahajan Sagar Bhaskar Ranjana, Nandyala Sreeramula Reddy, Repalle Kusala Pavan Kumar, Inukonda Rajesh "A Novel High Gain Dc-Dc Multilevel Boost Converter Using Voltage-Lift Switched-Inductor Cell" IEEE International Conference on Green Computing, Communication and Conservation of Electrical Energy (IEEEICGCCEE'14), Coimbatore (India).

[10] Mahajan Sagar Bhaskar Ranjana, Nandyala Sreeramula Reddy, Repalle Kusala Pavan Kumar "A Novel High Gain Floating Output DC-DC Multilevel Boost Converter for Fuelcell Applications" IEEE International Conference on Circuit, Power and Computing Technologies (IEEE-ICCPCT) 2014, Nagarcoil (India).

[11] Mahajan Sagar Bhaskar Ranjana, Nandyala Sreeramula Reddy, Repalle Kusala Pavan Kumar "A Novel Non-Isolated High Step-Up DC-DC Converters for Photovoltaic Applications" IEEE International Conference on Circuit, Power and Computing Technologies (IEEE-ICCPCT) 2014, Nagarcoil (India).

[12] Ching-Tsai Pan; Ching-Ming Lai; "A HighEfficiency High Step-Up Converter With Low Switch Voltage Stress for Fuel-Cell System Applications," Industrial Electronics, IEEE Transactions vol.57, no.6, pp.1998-2006, June 2010. 58)

[13] Mahajan Sagar Bhaskar Ranjana, Nandyala Sreeramula Reddy, Repalle Kusala Pavan Kumar "Non-Isolated Dual Output Hybrid DC-DC Multilevel Converter for Photovoltaic Applications" IEEE International Conference on Devices, Circuits and Systems (IEEE-ICDCS) 2014, Coimbatore (India).

[14] Mahajan Sagar Bhaskar Ranjana, Rishi M. Kulkarni, Kohkade Anita, Chandodkar Pooja "Non Isolated Switched Inductor SEPIC Converter Topologies for Photovoltaic Boost Applications" IEEE International Conference on Circuit, Power and Computing Technologies (IEEE-ICCPCT) 2016, Nagarcoil (India).

[15] Shih-Kuen Changchien; Tsorng-Juu Liang; Jiann-Fuh Chen; Lung Sheng Yang; "Novel High Step-Up DCDC Converter for Fuel Cell Energy Conversion System," Industrial Electronics, IEEE Transactions on, vol.57, no.6, pp.2007-2017, June 2010.

[16] Araujo, S.V.; Torrico-Bascope, R.P.; TorricoBascope, G.V.; "Highly Efficient High Step-Up Converter for Fuel-Cell Power Processing Based on Three-State Commutation Cell," Industrial Electronics, IEEE Transactions on , vol.57, no.6, June 2010 . 
[17] Ki-Bum Park; Gun-Woo Moon; Myung-JoongYoun; , "Non isolated High Step-up Boost Converter Integrated With Sepic Converter," Power Electronics, IEEE Transactions on , vol.25, no.9, pp.2266 2275, Sept. 2010.

[18] Mahajan Sagar Bhaskar Ranjana, Rishi Kulkarni, Sanjeevikumar Padmanaban, Pierluigi Siano, Frede Blaabjerg "Hybrid Non-Isolated And Non-Inverting Nx Interleaved DC-DC Multilevel Boost Converter For Renewable Energy Applications" The 16th IEEE International Conference on Environment and Electrical Engineering, (IEEE-EEEIC'16), Florence (Italy).

[19] Mahajan Sagar Bhaskar Ranjana, Rishi Kulkarni, Sanjeevikumar Padmanaban, Frede Blaabjerg, Viliam Fedák, Mihai Cernat "Non Isolated and NonInverting Cockcroft Walton Multiplier Based Hybrid 2Nx Interleaved Boost Converter For Renewable Energy Applications" IEEE Conf. on 17th The Power Electronics and Motion Control, (IEEE-PEMC'16), Varna, Bulgaria (Europe).

[20] Henn, G.; Silva, R.; Pra Ãßa, P.; Barreto, L.; Oliveira Jr, D.; "Interleaved Boost Converter With High Voltage Gain," Power Electronics, IEEE Transactions on , vol.PP, no.99.

[21] Mahajan Sagar Bhaskar Ranjana, P. Sanjeevikumar, F. Blaabjerg, OLourufemi Ojo, Shridhar Seshagiri, Rishi Kulkarni "Inverting $\mathrm{Nx}$ and $2 \mathrm{Nx}$ Non Isolated Multilevel Boost Converter for Renewable Energy Application" 4th IET International Conference On Clean Energy and Technology, (IET_CEAT16),Kuala Lumpur, Malaysia 2016.

[22] Mahajan Sagar Bhaskar Ranjana, P. Sanjeevikumar, Olorunfemi Ojo, Marco Rivera, R.Kulkarani, "NonIsolated and Inverting Nx Multilevel Boost Converter For Photovoltaic DC Link Applications" IEEE International Conference on Automatica, XXII Congress of the Chilean Association of Automatic Control, IEEE ICA/ACCA'16, University of Talca, Talca (Chile), 19-21 Oct. 2016.

[23] Mahajan Sagar Bhaskar Ranjana, P. Sanjeevikumar, F. Blaabjerg, Pat Wheeler, Marco Rivera, A. H. Ertas, R. Kulkarni "XY Converter Family: A New Breed of Buck Boost Converter for High Step-up Renewable Energy Applications" IEEE International Conference on Automatica, XXII Congress of the Chilean Association of Automatic Control, IEEEICA/ACCA'16, University of Talca, Talca (Chile), 19-21 Oct. 2016.

[24] Hyun-Lark Do; "A Soft-Switching DC/DC Converter With High Voltage Gain," Power Electronics, IEEE Transactions vol.25, no.5, pp.1193-1200, May 2010.

[25] Mahajan Sagar Bhaskar Ranjana, P. Sanjeevikumar, F. Blaabjerg, Rishi Kulkarni, Shridhar Seshagiri, Amin Hajizadeh "Novel LY Converter Topologies for High Gain Transfer Ratio- A New Breed of XY Family" 4th IET International Conference On Clean Energy and Technology, (IET_CEAT16), Kuala Lumpur, Malaysia 2016.
[26] Mahajan Sagar Bhaskar Ranjana, P. Sanjeevikumar, Frede Blaabjerg, Lars Norum, Ahmet Ertas "4Nx Non-Isolated and Non-Inverting Hybrid Interleaved Boost Converter Based On VLSI Cell and Cockroft Walton Voltage Multiplier for Renewable Energy Applications" IEEE International Conference On Power Electronics, Drives And Energy Systems, (IEEE-PEDES'16), Trivandrum, (India).

[27] Hwu, K.I.; Yau, Y.T.; "Voltage-Boosting Converter Based on Charge Pump and Coupling Inductor With Passive Voltage Clamping," Industrial Electronics, IEEE Transactions on , vol.57, no.5, pp.1719-1727, May 2010. 